\title{
VILJANKORJUUN TYÖNMENEKIN KEHITYKSESTÄ
}

\author{
ERKKi H. Oksanen \\ Maatalouden työtekniikan laitos, Helsingin Yliopisto
}

Saapunut 15.9. 1971

\begin{abstract}
ON THE DEVELOPMENT OF WORK CONSUMPTION IN GRAIN HARVEST
ERKKI H. OKSANEN

Department of Agricultural Engineering, University of Helsinki
\end{abstract}

\begin{abstract}
The study is based on material collected from eight book-keeping farms in South Finland during years 1948-64. As variables there have been man-, horse-, tractor-, and combine working hours per hectare on grain, yield per hectare, area on grain, the share of fields on winter rye and turnip rape $(\%)$, and the converted agricultural land area. Analysis of variance and t-tests have been used to find out the differences for variables between the farms, and between the study years. There have been significant differences in relation to all variables between the farms, and between the years in relation to work consumption figures. In variables man-, horse-, and self propelled combine hours, the variation between the years has been more than double when compared to that between the farms. In other variables the variation between the farms has been greater.

In stepwise multiple regression analysis, man work consumption has been explained best by horse working hours. When it has been the only predictor $\mathrm{R}^{2}$ has reached $0.7-$ 0.9 in different equations. Also tractor work consumption has been explained best by horse working hours, but other variables have come out often, too. Horse work consumption has been explained best by man working hours. The percentage variation explained in regression equations has in general been quite high, likewise the F-values of equations. Due to correlation between the variables, it has only seldom been possible to study separate regression coefficients.
\end{abstract}

Tutkimuksessa pyritään selvittämään viljankorjuun työnmenekkiin vaikuttaneita tekijöitä sekä eri tilojen ja vuosien välillä olevia vaihteluita. Kirjoitus on lyhennelmä Maatalouden työtekniikan laitoksen tutkimustiedotteesta n:o 2 (UKSANEN 1971).

Tutkimus perustuu kahdeksalta Etelä-Suomen alueen kirjanpitotilalta saatuun aineistoon kahdeksalta tilivuodelta (tilivuosi $=1$. 7.-30. 6.) vuosien 1948 ja -64 välillä. Tilat eivät muodosta mitään järjestelmällistä otosta mistään määrätystä perusjoukosta, joten tuloksia on pidettävä vain suuntaa-antavina. Yksityiskohtaisista työpäiväkirjoista on kerätty tiedot kunkin tilan viljankorjuutöiden ihmis-, hevos-, traktori- ja puimurityönmenekistä. Viljankorjuutöihin on luettu työt viljan leikkuusta jyvien ja olkien varastoon luovutukseen saakka.

Tutkimustilojen keskimääräinen muunnettu ala on ollut 41 ha. Kaikilla on harjoitettu sekä karjataloutta että viljanviljelyä koko tutkimuskauden ajan. Hevosten määrä on supistunut sen kuluessa $63 \%$. Traktori on ollut kahdella tilalla jo v. -48 , toisille se on han- 
kittu vuosina 1949-51. Oman tai vuokratun leikkuupuimurin käyttöä on esiintynyt vuodesta -53 lähtien.

Tutkimuskauden loppupuolella viljanviljely on lisääntynyt huomattavasti, mutta samalla rukiin ja syysrypsin viljely on supistunut. Hehtaarisadot ovat vaihdelleet lähinnä sääsuhteiden mukaan. Korjuukauden säät ovat olleet syksyinä -55 ja -59 hyvin suotuisat, syksyllä -57 kehnot ja muiden tutkimusvuosien syksyinä lähimain normaalit (Tutk. Suom. maatal. kann. XXXVII-XLVIII, tiliv. 1961-62 ja 1963-64). Tilojen keskimääräinen työnmenekki eri tutkimusvuosina esitetään taulukossa 1 ja kuviossa 1 .

Ihmistyönmenekin supistuessa tutkimuskaudella vajaaseen neljäsosaan hevostyönmenekki on vähentynyt vajaaseen kymmenesosaan. Tilivuoden 1957/58 huonojen korjuusäiden vaikutus näkyy työnmenekissä selvästi. Perusaineistosta on ollut todettavissa, että viljankorjuutöiden peltotyöjakso on tutkimuskauden alussa kestänyt 2.5 kuukautta, myöhemmin enää 1.5-2.0 kuukautta.

Taulukko 1. Keskimääräinen työnmenekki viljankorjuutöissä tutkimustiloilla.

Table 1. The average work consumption in grain harvest on the study farms.

\begin{tabular}{|c|c|c|c|c|c|c|c|c|}
\hline \multicolumn{3}{|l|}{ Työnmenekki vilja-ha kohti } & \multicolumn{2}{|c|}{ Tutkimus-tilivuosi } & \multicolumn{3}{|c|}{ Study business year } & \multirow[b]{2}{*}{$63 / 64$} \\
\hline Work consumption per hectare on grain & $48 / 49$ & $50 / 51$ & $53 / 54$ & $55 / 56$ & $57 / 58$ & $59 / 60$ & $61 / 62$ & \\
\hline Ihmistuntia & 111.6 & 84.0 & 78.0 & 48.4 & 64.8 & 44.7 & 41.8 & 26.1 \\
\hline \multicolumn{9}{|l|}{ Man hours } \\
\hline Hevostuntia & 36.5 & 28.9 & 24.5 & 16.5 & 21.1 & 10.3 & 9.5 & 2.47 \\
\hline \multicolumn{9}{|l|}{ Horse hours } \\
\hline Traktorituntia & 0.75 & 1.91 & 3.17 & 2.97 & 2.76 & 4.49 & 5.46 & 4.16 \\
\hline \multicolumn{9}{|l|}{ Tractor hours } \\
\hline Puimurituntia & 0.00 & 0.00 & 0.21 & 0.65 & 0.49 & 1.25 & 2.15 & 2.77 \\
\hline
\end{tabular}

TYÖNMENEKIN TARKASTELUA VARIANSSI- JA REGRESSIOANALYYSEIN

\section{Muttujat}

Tutkimusaineiston tietokonekäsittely on suoritettu Helsingin Yliopiston laskentakeskuksessa seuraavista muuttujista:

$$
\begin{aligned}
& \text { Muuttuja } \\
& \text { Variable } \\
& 1=\text { tila } \mathrm{n}: \mathrm{o} \\
& \text { farm No. } \\
& 2 \text { = vuosi n:o } \\
& \text { year } \mathcal{N o} \text {. } \\
& 3=\text { it./ha } \\
& \text { man hrs./hectare } \\
& 4=\text { ht. } / \text { ha } \\
& \text { horse hrs./hectare }
\end{aligned}
$$

$\begin{array}{cl}\begin{array}{c}\text { Vaihtelu } \\ \text { tutkimuskaudella } \\ \text { Variation during the study period }\end{array} & \begin{array}{c}\text { Käytettävä } \\ \text { lyhenne } \\ \text { Abbreviation used }\end{array} \\ 1-9 \text { (8 tilaa }+ \text { keskim. }) & \text { tila } 1 \ldots 8 \\ (8 \text { farms }+ \text { aver. }) & \text { farm } 1 \ldots 8 \\ 1-8 \text { (tutk. vuodet) } & \text { vuosi } 1 \ldots 8 \\ (\text { study years }) & \text { year } 1 \ldots 8 \\ 14.22-188.10 & \text { it. } \\ 0.00-56.59 & \text { ht. }\end{array}$

Käytettåvä Abreviation used

vuosi $1 \ldots 8$

year $1 \ldots 8$

ht. 


\begin{tabular}{|c|c|c|c|}
\hline \multicolumn{2}{|c|}{ Muuttaja } & $\begin{array}{c}\text { Vaihtelu } \\
\text { tutkimuskaudella }\end{array}$ & $\begin{array}{c}\text { Käytettävä } \\
\text { lyhenne }\end{array}$ \\
\hline Varia & ble & Variation during the study period & Abbreviation used \\
\hline $5=$ & $\begin{aligned}= & \text { trt. } / \text { ha } \\
& \text { tractor hrs./hectare }\end{aligned}$ & $0.00-21.44$ & trt. \\
\hline $6=$ & $\begin{aligned}= & \text { vetoleikkuupuimuritunteja/ha } \\
& \text { pull-type combine hrs./hectare }\end{aligned}$ & $0.00-5.00$ & vlp \\
\hline $7=$ & $\begin{array}{l}=\text { ajoleikkuupuimuritunteja/ha } \\
\text { self-propelled combine hrs./hectare }\end{array}$ & $0.00-5.01$ & alp \\
\hline $8=$ & $\begin{aligned}= & \text { vilja-sato } 100 \mathrm{ry} / \mathrm{ha} \\
& \text { grain yield } 100 \text { fodder units per hectare }\end{aligned}$ & $16.86-50.29$ & sato \\
\hline $9=$ & $\begin{aligned} & \text { vilja-ala ha } \\
& \text { grain acreage hectares }\end{aligned}$ & $7.65-28.00$ & v.-ala \\
\hline $10=$ & $\begin{array}{l}\text { rukiin plus rypsin prosenttiosuus vilja-alasta } \\
\text { the percentage share of fields on winter rye and } \\
\text { turnip rape }\end{array}$ & $0.00-36.90$ & $\mathrm{rr}$ \\
\hline $11=$ & $\begin{aligned}= & \text { muunnettu ala ha } \\
& \text { converted agricultural land hectares }\end{aligned}$ & $22.45-68.57$ & mha \\
\hline
\end{tabular}

Vetopuimurin työtunnit on erotettu ajopuimurin tunneista, koska edellinen tarvitsee traktorin veto- ja käyttövoimakseen. Rukiin plus rypsin osuus vilja-alasta on otettu muuttujaksi sen takia, että niiden korjuussa työnmenekki on suurempi kuin muiden viljojen korjuussa, esim. leikkuupuinnissa n. $50 \%$ suurempi (VAKolan koetusselostukset 160, 211, 292, 293, 353).

Tilan koon kasvaessa työnmenekki hehtaaria kohden supistuu (esim. OKsanen 1964). Tämän takia on otettu muuttujat "vilja-ala ha» ja "muunnettu ala ha». Hehtaarisadon nousu taas lisää työnmenekkiä (esim. HARAldson 1956); siksi muuttuja »vilja-sato 100 ry/ha».

Tälle havaintoaineistolle on suoritettu interkorrelaatioiden laskeminen ja siitä edelleen regressioanalyysit valikoivina. Tila- ja vuosieroja on tarkasteltu varianssianalyyseillä ja t-testeillä. Näitä testejä on - aineiston huomioonottaen — pidettävä lähinnä ohjeluontoisina yhteyksien voimakkuutta tarkasteltaessa.

Ihmis-, hevos- ja traktorityönmenekkilukuja on käytetty regressioanalyyseissä sekä selitettävinä että selittävinä muuttujina, muita vain selittävinä. Regressioanalyyseissä selittävien muuttujien tulisi olla toisistaan lineaarisesti riippumattomia samalla kuin niiden korrelaatioiden selitettävään muuttujaan tulisi olla mahdollisimman suuria. Käytännössä selittävät muuttujat kuitenkin usein korreloivat keskenään melkoisesti, jolloin erillisten regressiokerrointen tulkinta ja osittaisen mallin tarkastelu johtaa helposti virheellisiin päätelmiin (KULOKARI 1970). Tämän tutkimuksen muuttujien korrelaatiomatriisi koko aineistosta (8 tilaa, 8 vuotta, ts. 64 havaintoa) laskettuna on seuraava: 


\begin{tabular}{|c|c|c|c|c|c|c|c|c|}
\hline & $\begin{array}{l}\text { it. } \\
\mathrm{X}_{3}\end{array}$ & $\begin{array}{l}\text { ht. } \\
\mathrm{X}_{4}\end{array}$ & $\begin{array}{r}\text { trt. } \\
\mathrm{X}_{5}\end{array}$ & $\begin{array}{l}\text { vlp } \\
\mathrm{X}_{6}\end{array}$ & $\begin{array}{l}\text { alp } \\
\mathrm{X}_{7}\end{array}$ & $\begin{array}{c}\text { sato } \\
\mathrm{X}_{8}\end{array}$ & $\begin{array}{c}\text { v.-ala } \\
\mathrm{X}_{9}\end{array}$ & $\begin{array}{l}\mathrm{rr} \\
\mathrm{X}_{10}\end{array}$ \\
\hline$x_{4}$ & .855 & 1.000 & & & & & & \\
\hline $\mathrm{X}_{\mathrm{s}}$ & -.252 & -.458 & 1.0 & & & & & \\
\hline $\mathrm{X}_{6}$ & -.342 & -.402 & .384 & 1.0 & & & & \\
\hline $\mathrm{X}_{7}$ & -.442 & -.400 & -.137 & -.158 & 1.0 & & & \\
\hline $\mathrm{X}_{8}$ & .122 & -.133 & .530 & .174 & -.124 & 1.0 & & \\
\hline $\mathrm{X}_{9}$ & -.356 & -.102 & -.133 & .180 & .084 & -.388 & 1.0 & \\
\hline$X_{10}$ & -.079 & .063 & -.114 & -.073 & -.086 & -.330 & .124 & 1.0 \\
\hline$X_{11}$ & -.056 & .263 & -.275 & -.012 & -.041 & -.501 & .856 & .251 \\
\hline
\end{tabular}

Tällä havaintomäärällä $95 \%$ luotettavuustaso edellyttää vähintään korrelaatiota .246. Yli .500 korrelaatiot on selvennyksen vuoksi alleviivattu. Ihmis- ja hevostyö ovat korreloineet läheisesti (.855), ja muunnetun alan lisääntyessä myös tilan viljalla oleva peltoala on kasvanut $(.856)$. Suurten tutkimustilojen pellot ovat kuitenkin tuottaneet alhaisempia satoja kuin pienempien tilojen pellot (-.501).

Traktorityön ja sadon positiivinen korrelaatio on huomattava, mutta trt.:n ja ht.:n korrelaatio viljankorjuutöissä jää itseisarvoltaan jo alle .500:n. Vetovoiman ja puimurityön korrelaatiot ovat vielä pienempiä, samoin traktori- ja puimurityön korrelaatiot ihmistyöhön. Viimeksimainitut ovat kuitenkin suurempia kuin puimurityön korrelaatiot toisiin selittäviin muuttujiin $\mathrm{X}_{8}-\mathrm{X}_{11}$. Viimeksimainittujen korrelaatiot selitettäviin ovat yleensä pienehköt, mutta niillä ei myöskään, yllämainittuja poikkeuksia lukuunottamatta, ole korkeita keskinäisiä korrelaatioita. Näin ollen niillä voi odottaa olevan merkitystä työnmenekin selittäjinä.

\section{Eri tilojen ja vuosien vaikutus}

Eri tilojen ja vuosien välisen vaihtelun suhteellisen suuruuden ja eroavaisuuksien voimakkuuden toteamiseksi on käytetty t-testiä ja varianssianalyysiä. Eri tilojen ihmistyönmenekin suhteen on saatu seuraavat merkitsevät erot t-testillä:

$\begin{array}{cccc}\text { tilat } & 1 & 2 & 5 \\ 4 & 2.38^{*} & & \\ 5 & 3.04^{*} & 2.59^{*} & \\ 7 & & & -2.66^{*} \\ 8 & & & -2.70^{*}\end{array}$

Tilan 1 työnmenekki on ollut merkitsevästi pienempi kuin tilojen 4 ja 5 , ja tilojen 2 , 7 ja 8 merkitsevästi pienempi kuin tilan 5. Erot eri tutkimusvuosien välillä ovat:

$\begin{array}{llllll}\text { vuodet } & 48 / 49 & 50 / 51 & 53 / 54 & 55 / 56 & 57 / 58 \\ & & & & \\ 55 / 56 & -3.6^{* *} & -3.0^{*} & -2.4^{*} & & \\ 57 / 58 & -2.9^{*} & & & & \\ 59 / 60 & -4.0^{* *} & -3.6^{* *} & -2.9^{*} & & \\ 61 / 62 & -4.3^{* *} & -4.0^{* *} & -3.3^{*} & & \\ 63 / 64 & -6.1^{* * *} & -7.7^{* * *} & -6.2^{* * *} & -3.0^{*} & -5.6^{* * *}\end{array}$


Kuivan kesän -55 alhainen ja märän syksyn -57 korkea työnmenekki erottuvat selvästi yleisestä linjasta.

Yhden tekijän varianssianalyysit ilmaisevat työnmenekkikierot tilojen välillä merkitseviksi ja vuosien välillä erittäin merkitseviksi. Kaksisuuntaisella varianssianalyysillä on selvitetty tarkemmin tilojen ja vuosien välisten vaihteluiden suuruussuhteita. Varianssitaulu on seuraava:

\begin{tabular}{lcrrrr} 
var. lähde & neliösummat & $\%$ n.s.:sta & vap.ast. & var. & F \\
vuodet & 40316.28 & 57.3 & 7 & 5759 & $20.96 * * *$ \\
tilat & 16588.66 & 23.6 & 7 & 2370 & $8.62^{* * *}$ \\
jäännös & 13465.10 & 19.1 & 49 & 275 & \\
\hline yht. & 70370.04 & 100.0 & 63 &
\end{tabular}

Vuosien välinen vaihtelu ihmistyönmenekissä on ollut yli kaksinkertainen tilojen väliseen verrattuna. Selittämätön jäännös on vain vajaa viidesosa kokonaisneliösummista.

Hevostyönmenekki on ollut tilalla 4 merkitsevästi suurempi kuin tiloilla 1, 3, 5, 6 ja 7. Vuosien väliset erot ovat lähes samat kuin ihmistyönmenekin kohdalla. Samaten vuosien välinen vaihtelu on ollut yli kaksinkertainen tilojen väliseen nähden. Osuudet neliösummista ovat 62 ja $26 \%$, jolloin jäännös on $12 \%$. F-arvot ovat vastaavasti: vuodet $36.66 * * *$, tilat $15.21 * * *$.

Traktorityönmenekki on ollut tilalla 3 suurempi kuin tiloilla $1,2,4,7$ ja 8 . Tilalla 5 ei ole käytetty puimuria kuin vähän yhtenä vuonna (ihmistyönmenekki on myös ollut korkein), ja tilalla 6 on käytetty vetopuimuria kuten tilalla 3. Tilat 3 ja 6 erottuvat toisista vetopuimuritiloiksi myös vlp:n t-testissä. Vetopuimurin käytön erottaminen ajopuimurin työstä on täten asiallista.

Traktorin käytön lisääminen vuoden $48 / 49$ käytöstä on ollut merkitsevästi nollasta poikkeavaa vain tutkimuskauden loppupuolen vuosina. Vlp:ssä tilastollista eroa vuosien välillä ei ole. Molempien muuttujien suhteen tilojen välinen vaihtelu on ollut vuosien välistä suurempi. Koska konetyön käyttö eri tiloilla on alkanut eri vuosina ja määrä ollut erilainen samallakin tilalla eri vuosina, selittämätön jäännös neliösummista on noin $50 \%$.

Ajopuimuria on käytetty tilalla 2 merkitsevästi enemmän kuin tiloilla 3, 5 ja 7 . Kahteen ensimmäiseen tutkimusvuoteen nähden, jolloin puimureita ei ole ollut, sen käyttö on lisääntynyt merkitsevästi vuosina 55/56 ja 61/62. Ajopuimurin käytölle vuosien välinen varianssi on yli kaksinkertainen tilojen väliseen verrattuna. Selittämätön jäännös neliösummista on $58 \%$ samasta syystä kuin traktorityönmenekin kohdalla.

Varianssianalyysi on suoritettu myös sadosta ja rr:stä. Kummassakin on tilojen välillä merkitseviä eroja mutta ei vuosien välillä. Eri kokoisia tiloja: muunnettu ala alle 30 ha, 30 - 50 ha ja yli 50 ha, on myös verrattu toisiinsa. t-testin mukaan hehtaaria kohti laskettuja työnmenekkieroja ei ole esiintynyt. Tämän takia tiloja ei ole katsottu tarpeelliseksi jakaa eri ryhmiin tässä työnmenekkiin keskittyvässä tutkimuksessa, vaikka tilojen koko vaihteleekin melkoisesti.

Yhden tekijän varianssianalyyseillä ja t-testeillä on voitu osoittaa hyvin tilojen ja vuosien välisten erojen voimakkuusasteita ja siten saada esiin niille tunnusomaisia piirteitä. Kaksisuuntaiset varianssianalyysit puolestaan ovat selventäneet ja havainnollistaneet tilojen ja vuosien välisen vaihtelun merkitystä ja keskinäistä suuruutta tutkimusaineistossa. 


\section{Regressioanalyysit}

Y l e i s t ä. Tutkimuksessa on käytetty lineaarista valikoivaa regressioanalyysiä. Muuttujien mukaanottokriteerinä on pidetty $95 \%$ tilastollista luotettavuutta. Katkaisurajana yhtälön vaiheittaiselle jatkumiselle on ollut regressiokertoimen F-arvo 2.0 tai 2.3, mutta läheskään kaikkia tulostukseen tulleita selittäjiä ei lopullisiin yhtälöihin ole otettu. Tulostuksessa ovat olleet myös standardisoidut regressiokertoimet eli beta-kertoimet, jotka ilmaisevat kunkin selittäjän suhteellisen voimakkuuden. Hyvin hyödyllinen osa tulostuksessa ilmoittaa vielä, kuinka paljon yhtälöön jo hyväksytyt selittäjät selittävät jäljelläolevia muuttujia interkorrelaatioiden kautta.

Regressioyhtälöistä oleellisimmat ilmoitetaan vaiheittain. Samalla esitetään yhteiskorrelaatiokertoimen neliö $\mathrm{R}^{2}$ eli selitysaste sekä yhtälön F-arvo. Regressiokertoimien standardipoikkeamat ovat suluissa kerrointen alla. Joskus yhtälöön tullut selittäjä ei ole ollut kertoimeltaan tilastollisesti merkitsevä, mutta seuraavassa tai myöhemmässä vaiheessa se on muuttunut sellaiseksi. Myös jo merkitsevänä ollut selittäjä on voinut muuttua ei-merkitseväksi uuden selittäjän tullessa yhtälöön, jolloin edellinen on jäänyt pois lopullisesta yhtälöstä. Em. seikat johtuvat lähinnä muuttujien interkorrelaatioista (vrt. DrAPER ja Sмrтн 1967). Yhtälöitä (5)-(9) tarkasteltaessa käsitellään lähemmin muuttujien tulojärjestystä yhtälön selittäjiksi.

I h m is työnmenekin selit tämin en. Ihmistyönmenekin selitysyhtälöt ovat vaiheittain:

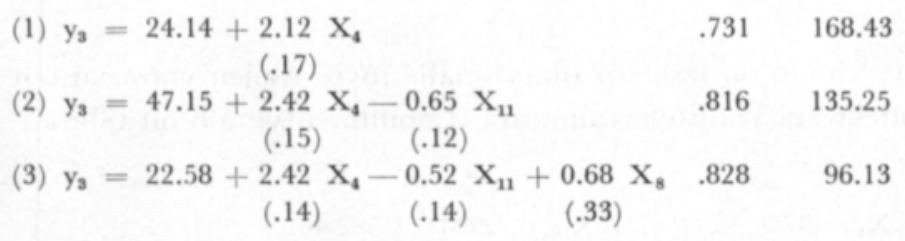

Korrelaatiomatriisin suhteen viitataan aikaisemmin sivulla 243 esitettyyn koko tutkimusaineiston muuttujien korrelaatiomatriisiin. Siinä todettu ihmis- ja hevostyönmenekin korkea korrelaatio osoittaa, että ht. tulee selittämään ihmistyönmenekkiä parhaiten. $X_{4}:$ n beta-kerroin on .93 eli nelinkertainen $X_{11}$ :n (mha) ja kahdeksankertainen sadon kertoimeen nähden. Vasta neljäntenä selittäjänä olisi tullut alp, mutta kertoimen F-arvo on vain 1.67 vaadittavan 4.0 asemesta, eikä se siten olisi nostanut mainittavasti selitysastettakaan. Interkorrelaatioista johtuen yhtälöön (3) hyväksytyt selittäjät selittävät jäljelläolevista muuttujista: $X_{5} 44 \%, X_{6} 21 \%, X_{7} 19 \%, X_{9} 85 \%$ ja $X_{10} 12 \%$.

Regressiokerrointen etumerkit ovat loogisia. $X_{4}: n$ kerrointa, joka ei paljoa muutu yhtälön eri vaiheissa voitaneen tarkastella yksinäänkin, etenkin kun $\mathrm{X}_{4}$ selittää lähes kolme neljännestä ihmistyönmenekin muutoksista. Kertoimen mukaan hevostyönmenekin muuttuminen tunnilla muuttaa ihmistyönmenekkiä samaan suuntaan noin 2.4 tuntia. Viljankorjuun työryhmässä tutkimuskaudella onkin yleisesti ollut $2-3$ henkeä hevosta kohti.

Yhtälön (3) F-arvo on 35-kertainen verrattuna F-arvoon $(3,60,0.95)=2.76$ (vapausasteet 3,60 , luotettavuustaso $95 \%$ ). Tyydyttävän ennustamiskyvyn omaavassa regressioyhtälössä tulisi eräiden esitysten mukaan F-suhteen olla ainakin nelinkertainen vastaavan F-jakautuman arvoon verrattuna (DRAPER ja SMITH 1967). 


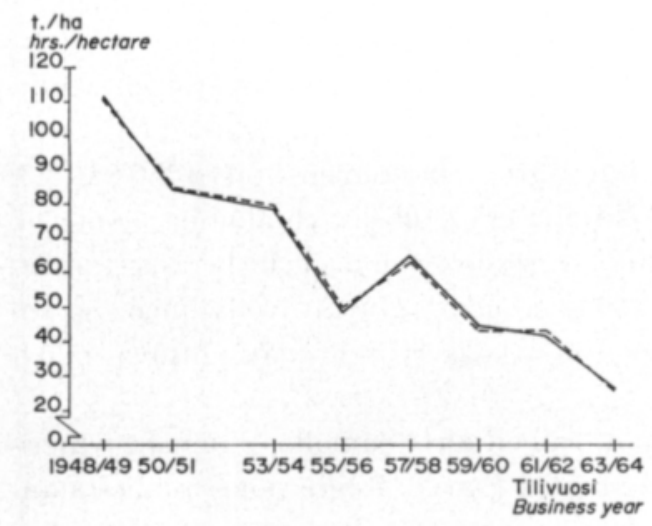

a. Ihmistyönmenekki - Man hours

- Todellinen kehitys - Actual development

... - Malli yhtälön (4) mukaan - Model according to equation (4)

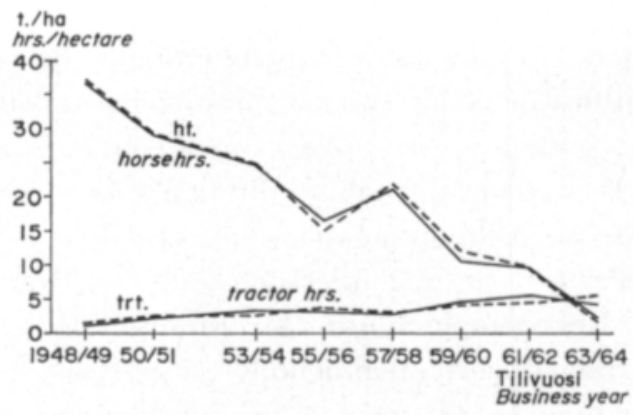

b. Hevos- ja traktorityönmenekki Horse and tractor work

Todellinen kehitys - Actual development

... Mallit yhtälöiden mukaan; hevostyö: yhtälö (13), traktorityö: yhtälö (17)

Models according to equations; horse work: equation (13), tractor work: equation (17)

Kuvio 1. Viljankorjuun työnmenekin kehitys tutkimustiloilla, työtuntia viljahehtaaria kohden, ja regressioyhtälöiden perusteella piirretyt mallit.

Fig. 1. Development of work consumption on study farms, working hours per hectare on grain, and models drawn according to regression equations.

Ihmistyönmenekin selitysyhtälö on laskettu tilaryhmälle myös tilojen vuosittaisten lukujen keskiarvosta, ts. kahdeksasta yhdistehavainnosta. Lopullinen yhtälö on tällöin:

(4) $\mathrm{y}_{3}=-83.25+\underset{(.06)}{2.37 \mathrm{X}_{4}+\underset{(.46)}{3.09 \mathrm{X}_{8}+}+\underset{(.33)}{1.34 \mathrm{X}_{10}} \quad .998 \quad 582.46}$

Korrelaatiomatriisi on tässä tapauksessa:

\begin{tabular}{llrrr} 
& & \multicolumn{1}{c}{$\mathrm{X}_{4}$} & $\mathrm{X}_{8}$ & $\mathrm{X}_{10}$ \\
$\mathrm{X}_{4}$ (ht.) & 1.000 & & \\
$\mathrm{X}_{8}$ (sato) & -.073 & 1.0 & \\
$\mathrm{X}_{10}$ (rr) & .295 & -.675 & 1.0 \\
$\mathrm{y}_{3}$ (it.) & .986 & .058 & .274
\end{tabular}

Havaintomatriisin alkioiden pienemmästä vaihtelusta johtuen päästään korkeampaan selitysasteeseen kuin yhtälössä (3), ja yhtälön F-arvo on 88-kertainen verrattuna F-arvoon $(3,4,0.95)=6.59$. Ht. yksin selittää $97 \%$ ihmistyönmenekistä, eikä sen kertoimen arvo muutu mainittavasti eri vaiheissa; hevos- ja ihmistyön suhde on tässäkin tapauksessa 1 ht. $\simeq 2.4$ it. Kuvioon 1a on piirretty malli yhtälön (4) perusteella. Se miltei yhtyy keskiarvoina laskettuun todelliseen kehitykseen, kuten korkea selitysaste edellyttääkin. Selittämätön jäännös on tasan jakautunut. Yhtälössä (4) rr on tullut merkitseväksi selittäjäksi yhtälössä (3) olleen mha:n asemesta. Interkorrelaatioiden kautta selittyy jäljelläolevista muuttujista $80-96 \%$.

Valikoivissa regressioanalyyseissä tiloittain selitysasteet ovat $.77 \ldots .99$ ja F-arvot 3. . 90-kertaisia vähimmäisvaatimukseen nähden. Kaikilla tiloilla ht. on merkitsevä ihmis- 
työnmenekin selittäjä, kolmella ainoa. Tilalla 1 alp ja sato, tiloilla 2 ja 3 trt. sekä tilalla 4 mha ovat lisäksi merkitseviä selittäjiä. Tilalla 8 niitä on peräti viisi; selitysyhtälö on vaiheittain:

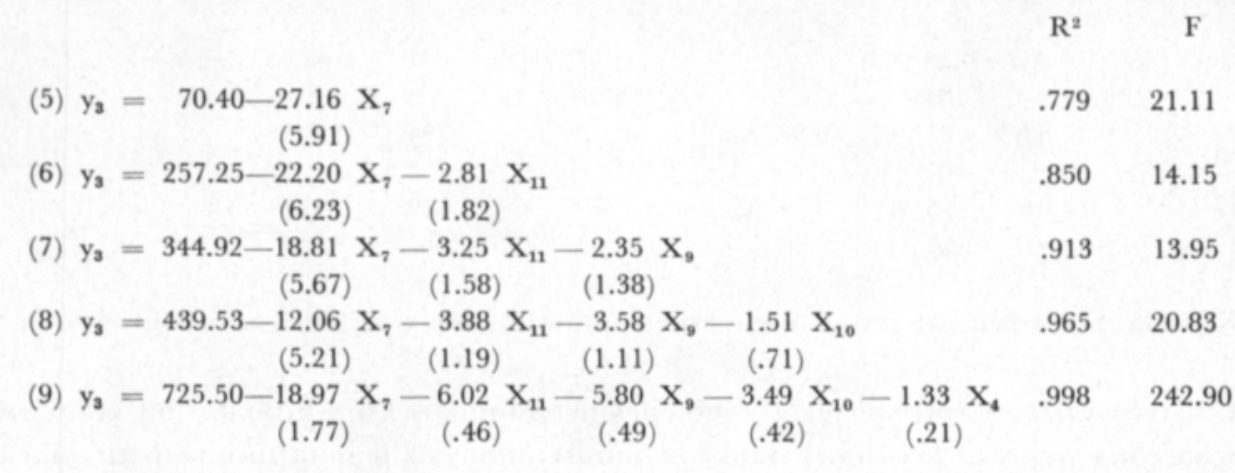

Selittäjien ja kriteerivariaabelin korrelaatiomatriisi on:

\begin{tabular}{|c|c|c|c|c|c|}
\hline & $x_{4}$ & $\mathrm{X}_{7}$ & $x_{9}$ & $\mathrm{X}_{10}$ & $\mathrm{X}_{11}$ \\
\hline $\mathrm{X}_{\mathbf{4}}$ (ht.) & 1.000 & & & & \\
\hline $\mathrm{X}_{7} \quad$ (alp) & -.842 & 1.0 & & & \\
\hline X, (v.-ala) & -.350 & .318 & 1.0 & & \\
\hline $\mathrm{X}_{10}(\mathrm{rr})$ & -.721 & .496 & -.162 & 1.0 & \\
\hline $\mathrm{X}_{11}$ (mha) & -.533 & .517 & .032 & .133 & 1.0 \\
\hline $\begin{array}{ll}y_{3} & \text { (it.) }\end{array}$ & .865 & -.882 & -.474 & -.485 & -.684 \\
\hline
\end{tabular}

Yhtälöissä (6)-(8) tulleiden selittäjien mha, v.-ala ja rr kertoimet eivät ole näissä tilastollisesti merkitseviä, mutta ht.:n tultua mukaan yhtälössä (9) kaikki selittäjät muuttuvat merkitseviksi. Tämä johtuu ht.:n ja toisten selittäjien interkorrelaatioista, joka näkyy korrelaatiomatriisista. Sen avulla voi tarkastella myös hyvin muuttujien tulojärjestystä yhtälöiden selittäjiksi. Ensimmäinen on $X_{7}$, jonka korrelaatio it.:n kanssa on suurin. Ht.:n korkean korrelaation takia alp:n kanssa se ei pääse toiseksi selittäjäksi, vaan siksi tulee mha, jolla on kolmanneksi korkein korrelaatio selitettävään. Samoin rr tulee vasta v.-alan jälkeen, koska rr:stä on selittynyt enemmän yhtälöön jo hyväksyttyjen selittäjien kautta. Lopuksi tulee ht., jolloin selitysaste nousee vielä huomattavasti.

Yhtälön (9) kaikkien selittäjien kertoimet ovat negatiivisia. Ht.:n ja rr:n kohdalta se tuntuu oudolta, mutta tällaisessa tapauksessa, jossa interkorrelaatiot ovat huomattavia ja selittäjiä on useita, kertoimien etumerkkejä ja suuruuksia ei voi tarkastella toisistaan riippumattomina.

Eri tutkimusvuosien yhtälöissä ht. on osoittautunut ihmistyönmenekin parhaaksi selittäjäksi tutkimuskauden alkuvuonna sekä koko loppupuoliskolla, lukuunottamatta viimeistä tutkimusvuotta, jolloin merkitseviä selittäjiä ei ole ollut. Toisena tutkimusvuonna trt. ja kolmantena alp on ollut ensimmäinen selittäjä. Muutkin muuttujat paitsi vlp ja mha ovat esiintyneet merkitsevinä selittäjinä yhtenä tai useampana vuonna. Selitysaste ja F-arvot ovat olleet tutkimuskauden jälkipuoliskolla suuremmat kuin alussa. 
Hevost yönmenekin selit tä mi n e n. Tilaryhmän yhtälöt ovat:

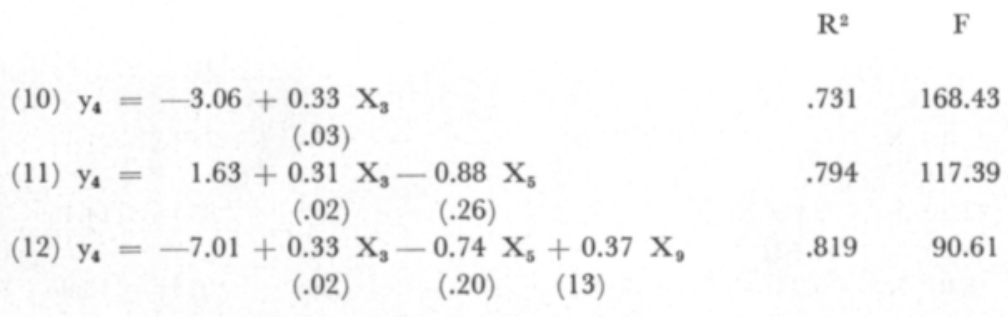

(Korrelaatiot selviävät muuttujien korrelaatiomatriisista s. 243)

It.:n tulo vastavuoroisesti hevostyönmenekin ensimmäiseksi selittäjäksi on odotettua. Lähes samana pysyvän kertoimen mukaan ihmistyönmenekin muuttuminen tunnilla on muuttanut hevostyönmenekkiä kolmasosatunnilla. Traktorityön lisääminen on vähentänyt hevostyötä, mutta suuruussuhdetta ei voi kertoimen epävakaisuuden takia esittää. V.-alan kautta heijastuu yhtälöön selittäjäehdokkaista poisjätetyn mha:n vaikutusta. Yhtälön (12) selittäjät selittävät jäljelläolevista muuttujista interkorrelaatioiden kautta 23$41 \%$,rr:stä kuitenkin vain $3 \%$. Ihmistyön suhteellinen voimakkuus on traktorityöhön nähden nelin- ja vilja-alaan nähden viisinkertainen; beta-kertoimet $.86,-.22 \mathrm{ja} .17$.

Yhtälön (12) F-arvo on 33-kertainen verrattuna F-arvoon $(3,60,0.95)=2.76$. Yhtälöissä (1) ja (10) $\mathrm{R}^{2}$ - ja F-arvot ovat täsmälleen samat, koska ne on laskettu samasta aineistosta vain it.:n ja ht.:n vaihtaessa paikkaa.

Tilojen vuosittaisten lukujen keskiarvoista laskien hevostyönmenekin lopulliseksi selitysyhtälöksi saadaan:
(13) $\mathrm{y}_{4}=28.27+\underset{(.03)}{0.31 \mathrm{X}_{3}-1.68 \mathrm{X}_{9}}$
$R^{2} \quad F$
$.993 \quad 334.52$

Korrelaatiomatriisi on seuraava:

$\begin{array}{lrc} & \mathrm{X}_{3} & \mathrm{X}_{9} \\ \mathrm{X}_{3} \text { (it.) } & 1.000 & \\ \mathrm{X}_{9} \text { (v.-ala) } & -.834 & 1.0 \\ \mathrm{y}_{4} \text { (ht.) } & .986 & -.903\end{array}$

Yhtälöön (12) verrattuna selittäjistä puuttuu trt., mutta selitysaste ja F-arvo ovat korkeammat. Kertoimien etumerkit ovat loogisia. Kuviosta 1b voidaan todeta yhtälön (13) perusteella piirretyn mallin miltei yhtyvän todellista kehitystä kuvaavaan murtoviivaan.

Tiloittaisissa yhtälöissä it. on hevostyönmenekin ainoana merkitsevänä selittäjänä tiloilla 4,5,6 ja 7. Tiloilla 1, 2, 3 ja 8 on lisäksi trt., sekä kolmantena selittäjänä tilalla 1 sato ja tilalla 2 alp. Tässä luettelossa on yhtymäkohtia varianssianalyysin antamiin tilojen tunnuspiirteisiin, mutta vielä lähemmin luettelo muistuttaa tiloittaista ihmistyönmenekin selittäjäluetteloa; onhan it.:n ja ht.:n välinen korrelaatio korkea. Selitysasteet tiloittain ovat $.84-.99$, paitsi tilalla 5 vain .67. Sillä myös F-arvo on pienehkö: 12.30 , eli kaksinkertai- 
nen vähimmäisvaatimukseen nähden, muilla tiloilla 33-153, paitsi tilalla 1 peräti 862 .

Eri tutkimusvuosien hevostyönmenekin selitysyhtälöissä it. esiintyy ensimmäisenä selittäjänä kolmena, trt. kahtena sekä alp ja sato kumpikin yhtenä vuonna. Merkitseviä selittäjiä vuonna 50/51 ei ollut. Tutkimuskauden jälkipuolen yhtälöissä trt. esiintyy selittäjänä kolmena vuonna, alkupuolella vain yhtenä. Traktorin käyttö siirtotöissä yleistyi 50-luvun puolivälissä. Hevostyö on epäilemättä korvautunut yleensä vetovoimaa vaatineissa töissä traktorityöllä, mutta viljankorjuussa puimurin käyttö on vähentänyt sekä hevos- että traktorityötä.

Traktorit yö n menekin s elit t ä minen. Traktorityönmenekin mahdollisista selittäjistä on jätetty pois v.-ala, $\mathrm{rr}$ ja mha. Selitysyhtälö on muodostunut vaiheittain:

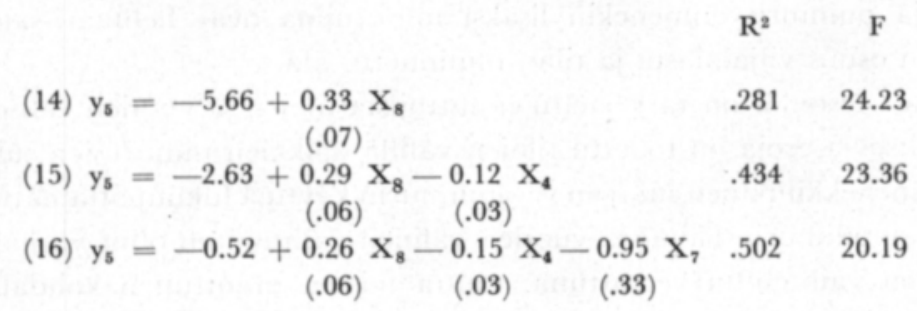

(Korrelaatiot; kts. muuttujien korrelaatiomatriisi s. 243).

Ht. tulee traktorityönmenekin selittäjäksi vasta korkeimman korrelaation traktorityöhön omanneen sadon jälkeen. Merkitsevät selittäjät selittävät jäljelläolevista muuttujista: $X_{3} 79 \%$ ja $X_{6} 29 \%$. Yhtälön (16) selitysaste on melko alhainen; myös varianssianalyysissä selittämätön jäännös oli suurehko. Yhtälön F-arvo on kuitenkin lähes 8-kertainen vaadittuun nähden. Kerrointen etumerkit ovat loogisia, mutta niiden arvo muuttuu interkorrelaatioiden takia eri vaiheissa siksi paljon, että on uskallettua esittää niiden perusteella korvaus- tai muita suhteita.

Tilojen vuosittaisista keskiarvoista laskettu regressioyhtälö on:

(17) $\mathrm{y}_{\mathrm{b}}=5.43-0.12 \mathrm{X}_{4} \quad \mathrm{R}^{2}=.795 \quad \mathrm{~F}=23.26$

Kuviossa lb on tämän yhtälön perusteella piirretty malli. Vaikka selittäjänä on vain ht., päästään korkeampaan selitysasteeseen kuin yhtälössä (16), mutta F-suhde on huonompi. Ht. selittää interkorrelaatioiden kautta jäljelläolevista muuttujista $78-97 \%$, sadosta kuitenkin vain $1 \%$. Hevostyön regressiokerrointa ei voi täten tulkita niin, että viljankorjuutöissä yksi traktoritunti vastaisi kahdeksaa hevostuntia $(8 \times 0.12 \simeq 1.0)$. Tämä ei ole käytännössä mahdollistakaan. Aikaisemmin kirjoittaja on laskenut korvaussuhteen 3 . . 5 tunniksi (OKsanen 1963).

Tiloilla 1-4 merkitseviä traktorityönmenekin selittäjiä ei ole, tilalla 5 sellaisena on sato, tilalla 6 vlp ja tiloilla 7 ja 8 trt. Edellisellä on toisena selittäjänä alp. Nämä käyvät yksiin tilojen tunnuspiirteiden kanssa vain tilojen 5 ja 6 kohdalla. Eri yhtälöissä $\mathrm{F}$-arvot ovat pienehköjä (9.92-19.12) mutta selitysasteet tyydyttäviä (.62-.82). Tutkimusvuosittaisten yhtälöiden mukaan tutkimuskauden loppupuolella puimurityö yhdessä sadon kanssa on selittänyt traktorityön melko hyvin. 
Vaikka tutkimustuloksilla on oman maamme 1970-luvun viljankorjuun työnmenekkiä ennustettaessa hyvin rajoitettu merkitys, ne kuitenkin kuvaavat suhteellisen hyvin aikaisempaa kehitystä ja osoittavat tiloittaiset erot ja niiden vaikutuksen tutkimustuloksiin pienehkössä aineistossa. Samalla tutkimus osoittaa työnmenekkiin vaikuttavien tekijöiden moninaisuuden ja toisiinsa liittymisen, ts. useissa yhteyksissä todetuilla interkorrelaatioilla on hyvin vahva vastineensa käytännössä.

\section{Ti ivis te $1 \mathrm{~m}$ ä}

Tutkimus perustuu kahdeksalta Etelä-Suomen alueen kirjanpitotilalta kerättyyn aineistoon kahdeksana tilivuonna vuosien 1948 - 64 välillä. Viljahehtaaria kohden lasketun ihmis-, hevos-, traktori- ja puimurityönmenekin lisäksi muuttujina ovat hehtaari-sato, vilja-ala, rukiin plus rypsin osuus vilja-alasta ja tilan muunnettu ala.

Varianssianalyyseillä ja t-testeillä on tarkasteltu muuttujista tilojen ja vuosien välisen eron voimakkuutta. Merkitseviä eroja on todettu tilojen välillä kaikkien muuttujien suhteen ja vuosien välillä työnmenekkilukujen suhteen vetopuimurin käyttöä lukuunottamatta. Ihmis- ja hevostyön sekä ajopuimurin käytössä vuosien välinen vaihtelu on ollut yli kaksinkertainen tilojen väliseen vaihteluun verrattuna, mutta toisten muuttujien kohdalla tilojen välinen vaihtelu on ollut vuosien välistä suurempi.

Ihmistyönmenekin paras selittäjä on ollut hevostyö sekä tilaryhmälle kokonaisuudessaan että eri tiloille ja eri tutkimusvuosina. Selitysaste on ollut pelkästään sitä käyttäen $0.7-0.9$. Eri yhtälöissä ovat esiintyneet vetopuimurin käyttöä lukuunottamatta muutkin muuttujat tilastollisesti merkitsevinä selittäjinä.

Hevostyönmenekin paras selittäjä on vastavuoroisesti ollut ihmistyö, mutta kaikki muutkin muuttujat ovat olleet yhdessä tai useammassa yhtälössä merkitsevinä selittäjinä. Traktorityönmenekille hevostyö on ollut yleisimmin esiintynyt selittäjä, mutta muitakin on ollut usein.

Regressioyhtälöiden selitysasteet ovat olleet yleensä korkeahkoja, samoin yhtälöiden F-arvot havaintojen vähyydestä huolimatta. Interkorrelaatioiden takia regressiokertoimia ei ole yleensä voitu tarkastella toisistaan riippumattomina. Kuitenkin on pääteltävissä, että hevostyönmenekin muuttuessa tunnilla ihmistyönmenekki on muuttunut samaan suuntaan noin 2.5 tuntia.

\section{KIRJALLISUUTTA}

Draper, N. R. \& Sмrth, H. 1967. Applied regression analysis. 407 p. New York-London-Sydney.

Haraldson, A. 1956. Arbetets effektivitet och organisation. Lantbrukets driftsekon. 4: 111-178. Stockholm.

KULOKARI, H. 1970. Tilastollisesta tietojenkäsittelystä Helsingin yliopiston laskentakeskuksessa. Helsingin yliopiston laskentakeskuksen julk. 2/170: $1-67$.

OKsanen, E. H. 1963. Koneellistamisen vaikutuksia työnmenekkiin ja organisaatioon Etelä-Suomen kirjanpitotiloilla. Suom. Maatal.tiet. Seur. Julk. 101: 1-170 + 16 liit. Diss.

——- 1964. Maataloustyö ja maatalouden koneellistuminen. Maanviljelijän tietokirja 3, 4: 161-237. Porvoo-Helsinki,

-»—1971. Viljankorjuun työnmenekin kehityksestä. Maatalouden työtekniikan laitoksen tutkimustiedote 2: 1-30. Moniste.

Tutkimuksia Suom. maatal. kannattavuudesta XXXVII-XLVIII, tilivuodet 1961/62, 1963/64.

VAKolan koetusselostuksia, N:ot 160, 211, 292, 293 ja 353. 